\title{
Kinematics of the East Anatolian Fault Zone between Turkoglu (Kahramanmaras) and Celikhan (Adiyaman), eastern Turkey
}

\author{
Huseyin Yilmaz ${ }^{1}$, Semir Over ${ }^{2}$, and Suha Ozden ${ }^{3}$ \\ ${ }^{1}$ Cumhuriyet University, Department of Geophysics, 58140 Sivas, Turkey \\ ${ }^{2}$ Mustafa Kemal University, Department of Geophysics, Hatay, Turkey \\ ${ }^{3}$ Canakkale Onsekiz Mart University, Faculty of Engineering and Architecture, Terzioglu Campus, Department of Geology, \\ 17020, Canakkale, Turkey
}

(Received June 13, 2005; Revised February 17, 2006; Accepted July 12, 2006; Online published December 25, 2006)

\begin{abstract}
In this study we determined the stress regime acting along the East Anatolian Fault Zone between Turkoglu (Kahramanmaras) and Celikhan (Adiyaman), from the Neocene to present-day, based on the inversion of striations measured on faults and on the focal mechanisms of earthquakes having magnitudes greater than 5.0. The inversions yield a strike-slip stress regime with a reverse component (i.e., transpression) operative in the Neocene to present with a consistent N-to NW-trending $\sigma_{1}$ axis $156 \pm 11^{\circ}$ and an E- to NE-trending $\sigma_{3}$ axis, $67 \pm 9^{\circ} \sigma_{3}$, producing left-lateral motion along the East Anatolian Fault Zone. The inversions of focal mechanisms yield a strike-slip stress deviator characterized by an approximately $\mathrm{N}-\mathrm{S}\left(\mathrm{N} 1^{\circ} \mathrm{W}\right)$-trending $\sigma_{1}$ and an approximately $\mathrm{E}-\mathrm{W}\left(\mathrm{N} 89^{\circ} \mathrm{E}\right)$-trending $\sigma_{3}$ axis. Both the kinematic analysis and structural observations indicate that the stress regime operating in the study area has had a transpressional character, giving rise to the Mio-Pliocene compressive structures (reverse faults, thrusts and folds) observed in the study area. Field observations allow estimation of a Pliocene age for the strike-slip East Anatolian Fault Zone.
\end{abstract}

Key words: Anatolia, East Anatolian Fault, stress state, earthquake, fault-slip inversion.

\section{Introduction}

Africa-Eurasian convergence and the Arabia-Eurasia collision zones profoundly influence the eastern Mediterranean tectonic framework (Fig. 1). Continental collision is responsible for the thickening of the crust in eastern Turkey and compressional deformation along Bitlis Suture Zone (BSZ in Fig. 1) (Dewey et al., 1986; Keskin, 2003; Zor et al., 2003). Sandvol et al. (2003) pointed out that there is no significant crustal thickening but there is a significant dipping sub-Moho structure along the East Anatolian Fault Zone (EAFZ). They also showed the presence of an apparent crustal low velocity zone within the Anatolian subplate. Continental collision also has occurred along the leftlateral EAFZ, between the Anatolian block and the Arabian plate. The EAFZ was first described by Allen (1969) and mapped by Arpat and Saroglu (1972), Seymen and Aydin (1972), Arpat and Saroglu (1975), Saroglu et al. (1992), and Imamoglu (1993). It is a belt of active seismicity and tectonics that joins the eastern end of another major Anatolian fault, the right-lateral North Anatolian Fault Zone (NAFZ), at Karliova, extending to the Amik Basin near Antakya (Arpat and Saroglu, 1972; Perincek and Cemen, 1990; Saroglu et al., 1992; Over et al., 2004a) or to the Gulf of Iskenderun (McKenzie, 1972; Jackson and McKenzie, 1988). The NAFZ runs approximately $1400 \mathrm{~km}$ from its interaction with the EAFZ in the east to the northern Aegean

Copyright (c) The Society of Geomagnetism and Earth, Planetary and Space Sciences (SGEPSS); The Seismological Society of Japan; The Volcanological Society of Japan; The Geodetic Society of Japan; The Japanese Society for Planetary Sciences; TERRAPUB. in the west. The NAFZ and EAFZ are two of the most active continental transform fault zones in the world and constitute high-risk zones in Turkey (McKenzie, 1972; Sengor, 1979; Dewey and Sengor, 1979; Bellier et al., 1997). The NAFZ has generated a systematic westward migration of large earthquakes since the 1939 Erzincan catastrophic event; conversely, the EAFZ has been relatively quiescent, with only three large events in the last century (Ambraseys, 1989). However, seismic records suggest that the EAFZ has accumulated significant stresses along its length. Turkelli et al. (2003) observed a difference in the seismogenic thickness between the NAFZ and EAFZ. These Anatolian fault zones contribute to the westward movement of the Anatolian block that resulting from the northward drift of the Arabian plate. Although the Anatolian-domain fault kinematics and stress-regime history are poorly known, especially along the EAFZ, the Late Cenozoic stress regimes of western Anatolia (e.g., Angelier et al., 1981; Zanchi and Angelier, 1993), the central NAFZ (e.g., Bellier et al., 1997; Over et al., 1997; Ozden et al., 2002), and the southern part of the EAFZ in the Kahramanmaras-Adana-Antakya area (Lyberis et al., 1992; Over et al., 2002, 2004a, b) are relatively well understood.

In this paper, we discuss measured fault-slip vectors and seismic fault-slip inversions in order to determine the paleoand present day-stress regimes and their tectonic implications along the EAFZ between Turkoglu (Kahramanmaras) and Celikhan (Adiyaman). 


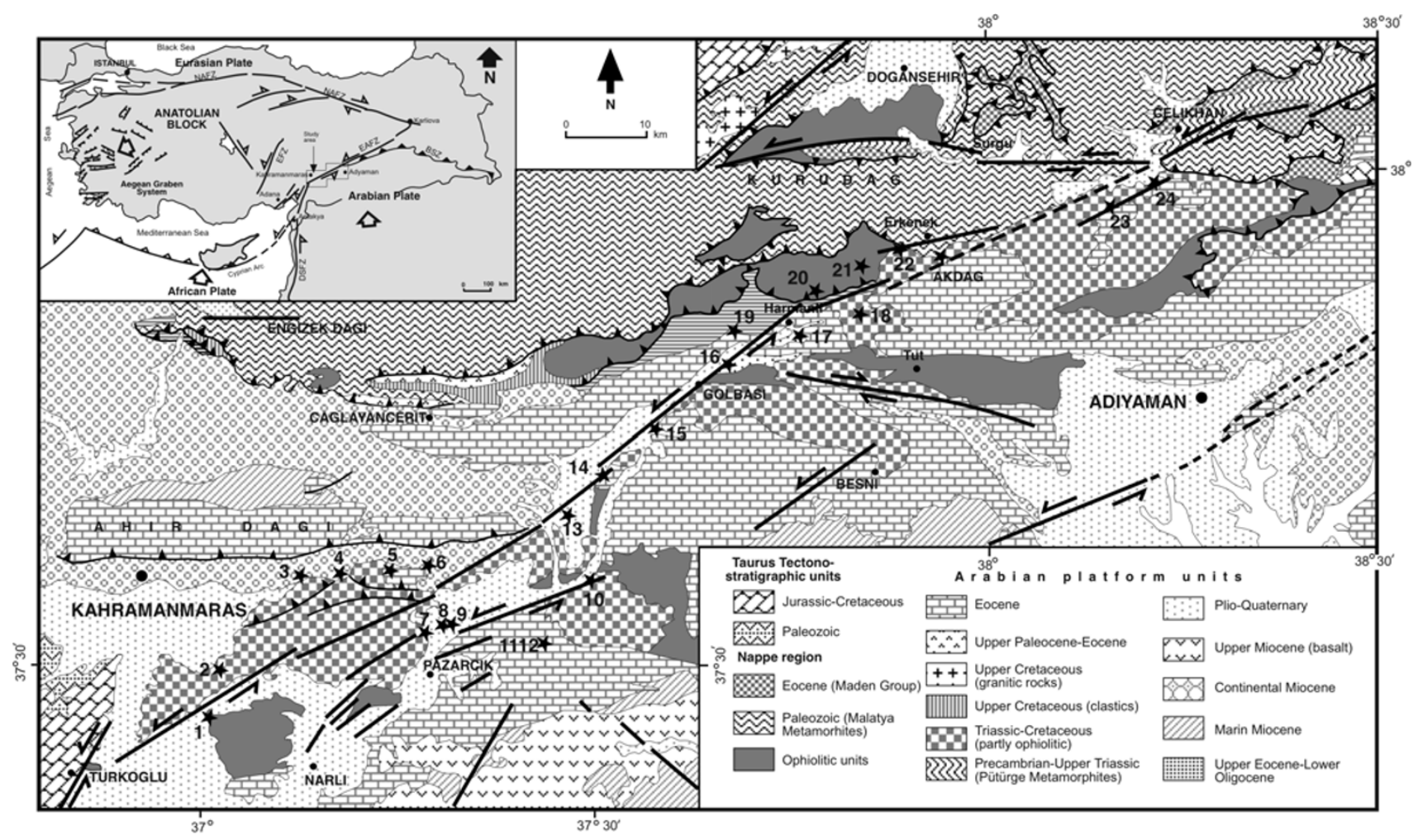

Fig. 1. Detailed geological map of the study area (modified after Yalçın, 1979; Imamoglu, 1993; Ulu, 2002 and Bilgic 2002). Stars and numbers indicate the locations of the fault slip measurement sites.

\section{The East Anatolian Fault Zone 2.1 Geological setting}

The neotectonic regime of Turkey is mainly controlled by the continuing northward motions of the African and Arabian plates with respect to Eurasian plate, which began in the Middle-Late Miocene and resulted in the westward extrusion of the Anatolian block along the North and East Anatolian fault zones (McKenzie, 1972; Dewey and Sengor, 1979; Sengor and Yilmaz, 1981; Jackson and McKenzie, 1988). The EAFZ begins at the Karliova triple junction and extends to the southwest for about $600 \mathrm{~km}$ until it reaches another triple junction at the Amik basin, near Antakya (Over et al., 2004c). The translation rates of these plates are actually well constrained by GPS measurements throughout the region (Reilinger et al., 1997; McClusky et al., 2000), and the 18 - to $25-\mathrm{mm} / \mathrm{yr}$ northward motion of the Arabian plate results in a $9 \mathrm{~mm} / \mathrm{yr}$ left-lateral motion along the EAFZ (McClusky et al., 2000). This major fault consists of several local parallel and sub-parallel, left-lateral strike-slip faults with considerable normal and reverse components. Based on the strike of the segments, the EAFZ should consist of six segments (Saroglu et al., 1992); however, Hempton et al. (1981) defined only five segments based on geometry and behavior, while Barka and Kadinsky-Cade (1988), based on fault geometry and seismic activity, suggested that there may be 14 different segments along the EAFZ. The segment between Turkoglu and Celikhan has experienced earthquake events on March 2, $1893(M=7.1,45 \mathrm{~km})$, December 4, $1905(M=6.8,38$ $\mathrm{km})$, and most probably on March 28, $1513(M=7.4,103$ km) (Ambraseys and Jackson, 1998; Nalbant et al., 2002).
The study area, which is the southeast Anatolian orogenic belt, comprises different tectonic units with various lithological sequences (Fig. 1). Upper Paleozoic carbonate and clastic rocks and Jurassic-Cretaceous limestone (Taurus units) occur in the west of the Amanos Fault, the western part of the study area. The eastern part of the study area consists of a nappe region in the north and an imbricated zone and Arabian platform in the south (Yilmaz, 1993). The nappe region comprises an upper nappe consisting of the Paleozoic-Triassic Malatya Metamorphites, and a lower nappe of Upper Cretaceous ophiolites and associated rocks and the Middle Eocene Maden Group that unconformably underlies the Upper Cretaceous ophiolites and Precambrian-Upper Triassic Puturge Metamorphites (Yazgan and Chessex, 1991). The zone of imbrications consists of a number of imbricated thrust slices with a southerly vergence (Yilmaz et al., 1987; Yilmaz, 1990; Karig and Kozlu, 1990). Rocks in the thrust slice range in age from Late Cretaceous to Early Miocene (Yilmaz, 1993). The Arabian Platform in the study area comprises, from bottom to top, Triassic-Cretaceous pelagic limestone, radiolarite, chert, clastic rocks, volcanic rocks and local ophiolitic sheets, Upper Cretaceous clastic and carbonate rocks, Upper Paleocene-Eocene volcanic and sedimentary rocks, Eocene clastic rocks and neritic limestone, Upper Eocene-Lower Miocene volcanic and sedimentary rocks, Lower Miocene clastic rocks and neritic carbonates, Middle-Upper Miocene neritic carbonates, and continental clastic rocks. Plio-Quaternary neotectonic continental rocks uncomformably overlie these older rock units.

The age of the EAFZ is highly controversial, with pro- 


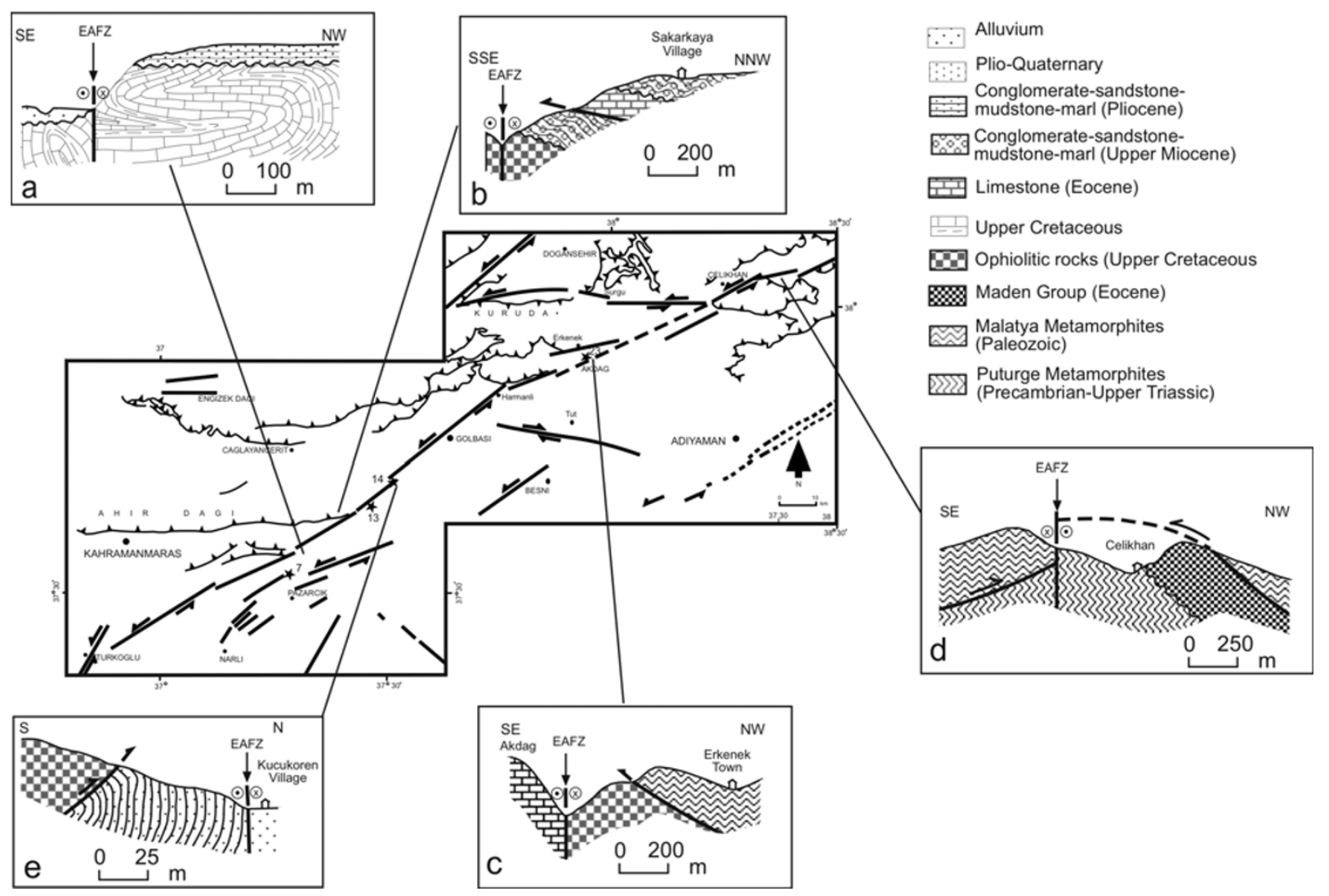

Fig. 2. (a)-(e) Some characteristic cross-sections with folding and thrust faults related to the deformation style of the EAFZ (between Turkoglu and Celikhan) in the period from the Late Cenozoic to present. Stars and numbers indicate the locations of the measurement sites.

posals of Late Miocene-Early Pliocene (Sengor et al., 1985; Dewey et al., 1986; Hempton, 1987; Arpat and Saroglu, 1972; Perincek and Cemen, 1990; Lyberis et al., 1992), Late Pliocene (Saroglu et al., 1987; Saroglu et al., 1992), 1.8 Ma (Yurur and Chorowicz, 1998), 3 Ma (Westaway and Arger, 1998) and 4 Ma (Westaway, 2003). Our field observations show that the EAF developed after a folding-thrusting deformation event that operated until at least the Pliocene. Normal faults observed in the Upper Miocene continental deposits are situated in front of the E-W-striking N-to-S upthrusts (Fig. 2(a)-(e)). This deformation style can be considered as evidence of the extension in front of the Late Miocene thrust belt. Upper Cretaceous ophiolitic rocks have been thrust onto an unconsolidated continental red conglomerate of probable Plio-Quaternary age at a site $10 \mathrm{~km}$ southeast of Golbasi (Fig. 2(a)). This south-vergent retrocharriage deformation type (or back-thrust faults) indicates a transpressive/compressive regime, with N-S shortening during PlioQuaternary time. The deformation style of the EAFZ has been related to folding, thrust faulting (Figs. 3(a)-(b)), and strike-slip and normal faulting (Fig. 4(a)-(b) since the Late Miocene. During this period, all structures in eastern Turkey were caused by the northward drift of the Arabian plate. For example, the EAFZ separates the Puturge Metamorphites in the northwest from the Malatya Metamorphites in the southeast, near Celikhan. Between Celikhan and Akdag, the fault locally follows the contact of the Triassic-Cretaceous and Eocene units (Sites 23-24), and elsewhere lies within the Triassic-Cretaceous units. The EAFZ cuts the Malatya Metamorphites near Erkenek and forms the boundary between the Triassic-Cretaceous and Eocene units between Erkenek and Akdag (Site 23). From there, the EAFZ continues toward the southwest within the Triassic-Cretaceous units, between Akdag and Harmanli. The fault cuts through Plio-Quaternary deposits, Eocene rocks, and ophiolitic rocks between Harmanli and Turkoglu and forms the Plio-Quaternary basins near Golbasi and Pazarcik. Lyberis et al. (1992) suggested that dominant structures occurring between Kahramanmaras and Golbasi are thrusts, involving the Mesozoic, Eocene and Neocene formations. In actuality, the deformation styles related to the pre-Plio-Quaternary folding-thrusting tectonics are widespread in the area between Turkoglu (Kahramanmaras) and Celikhan (Adiyaman). For example, the EAFZ cuts Upper Cretaceous folded sedimentary rocks comprising alternating limestone-marl-clay that is unconformably underlain by Plio-Quaternary deposits (Figs. 2(a), 3(b)) at site 7 to the north of Pazarcik. The axes of these recumbent folds are oriented N-S. Eocene limestone is thrust over (Nacar overthrust; Yalcin, 1979) an Upper Miocene alternation of conglomerate-sandstone-mudstone in the northern block of the EAFZ south of Sakarkaya village to the west of Golbasi (Fig. 2(b)). Some similar overthrusting is present in the Triassic-Cretaceous units (Fig. 1). Near Erkenek, Upper Cretaceous ophiolitic rocks (Kocali complex) beneath the Malatya Metamorphites nappe have been juxtaposed with Eocene limestone of the Arabian autochthon 


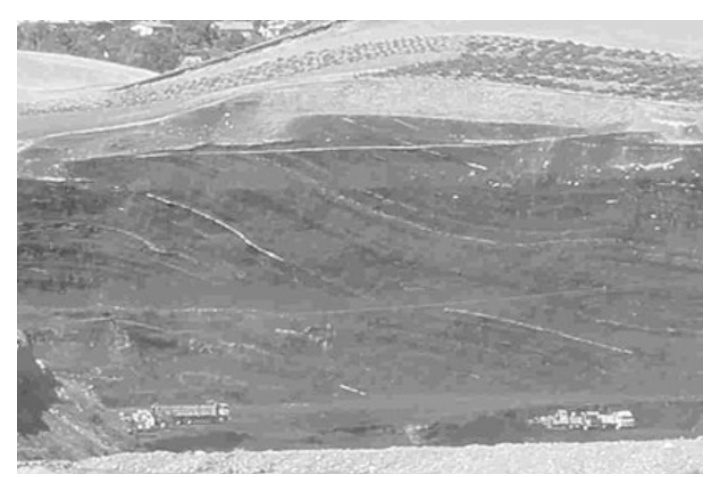

a)

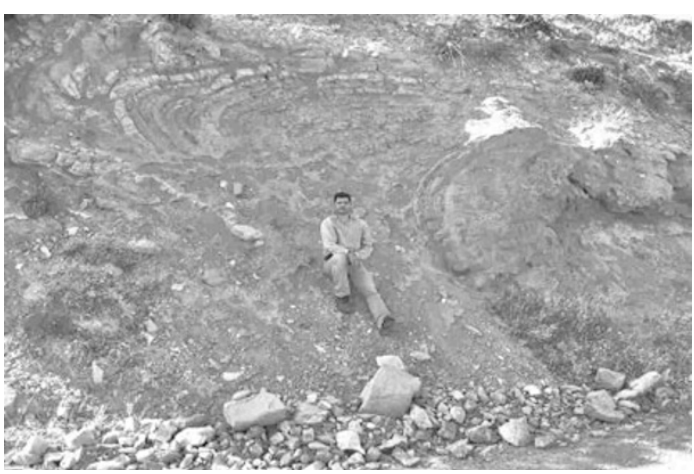

b)

Fig. 3. These pictures illustrate the type of folding along the EAFZ. (a) Monoclinal or flexure folding are present in the Pliocene coal layers (north of site 16, photo is in a NW-SE direction). (b) Upper Cretaceous limestone with recumbent folding. For site location, see Fig. 2, north of site 7. Photo is in a W-E direction.

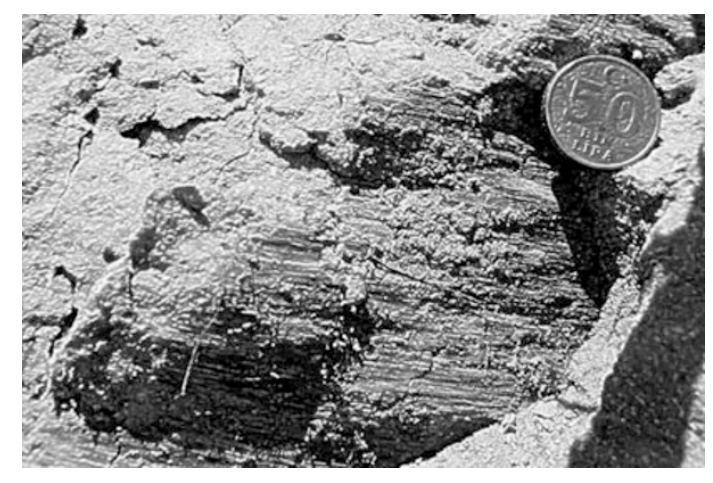

a)

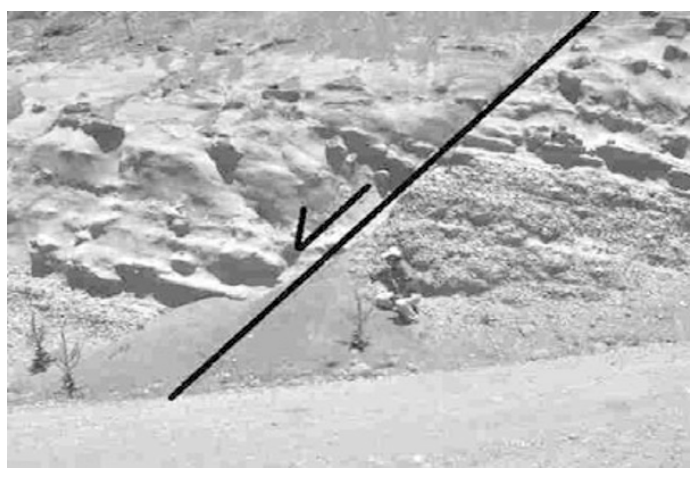

b)

Fig. 4. (a) Photograph of strike-slip faulting on a fault plane affecting the Miocene deposits at site 6. Photo is in a N-S direction. (b) Photograph of normal faulting (slip is $4 \mathrm{~m}$ ) affecting the Pleistocene conglomerates at site 10. Photo is in the N-S direction.

(Fig. 2(c)). All of these compressional structures have been cut by the EAFZ. For example, the Malatya Metamorphites nappe that was emplaced in the Late Miocene (Yilmaz, 1993) of this region is cut by the EAFZ near Celikhan (Fig. 2(d). Moreover, the EAFZ cuts open folds in sedimentary rocks containing a lignite layer (Fig. 3(a)). A fossil assemblage, including Laevigatosporites haardti (Pot. And Ven.) Th. and Pf., Inaperturopollenites dubius (Pot. And Ven.) Th. and Pf., Ptyosporites labdacus (Pot.) Th. and Pf., Ptyosporites microalatus (Pot.) Th. and Pf., Monopropollenites graminoides Meyer; Triatriopollenites coryphaeus (Pot.) Th. and Pf., Triatriopollenites cingulum Pot. (Th. and Pf.), Triatriopollenites densus Pf., Triatriopollenites liberansis Th., Triatriopollenites sp., Compositae, Graminae), indicating a Pliocene age, was reported from this unit by Imamoglu (1993).

\subsection{Seismicity}

Both historical and instrumental records reveal that the study area has been affected by destructive earthquakes for almost 2000 years (Willis, 1928; Sieberg, 1932; Ergin et al., 1967; Ambraseys, 1970, 1989; Soysal et al., 1981; Orgulu et al., 2003; Turkelli et al., 2003). This area is also known from historical catalogues to have been seismically active (Poirier and Taher, 1980; Ambraseys and Barazangi, 1989; Ambraseys and Melville, 1995). The distribution of earth- quakes along the major fault sytems of Turkey is controlled by the relative motions of the Eurasian (e.g., represented by the Anatolian block), African, and Arabian plates. However, despite its high historical seismicity, the EAFZ has been characterized by low seismicity during the past century (Jackson and McKenzie, 1988; Ambraseys and Jackson, 1998). The EAFZ is segmented, with different segments having different expressions (Hempton et al., 1981; Barka and Kadinsky-Cade, 1988; Saroglu et al., 1992). The segment between Turkoglu (Kahramanmaras) and Celikhan (Adiyaman) was largely formed by the largest of the known historical earthquakes, which occurred in the study area on November 29, $1114(M>7.8)$, March 28, 1513 $(M>7.4)$, and March 2, 1893 ( $M>7.1)$ (Fig. 5) (Ambraseys and Jackson, 1998; Nalbant et al., 2002). A deployment of a dense seismic network revealed that the seismic activity in Eastern Turkey is higher than previously observed and that the major events may originate in the lover crust $(H>20 \mathrm{~km})$ (Turkelli et al., 2003). Figure 5 is a seismotectonic map showing the major fault systems and earthqauke epicenters (both instrumental and historical) in the area. Table 3 is a list of some selected earthquakes. The most destructive earthquake recorded since 1900 was on December 4, $1905(M>6.8)$ and caused a 38-km-long surface rupture in the northern end of the present study area 


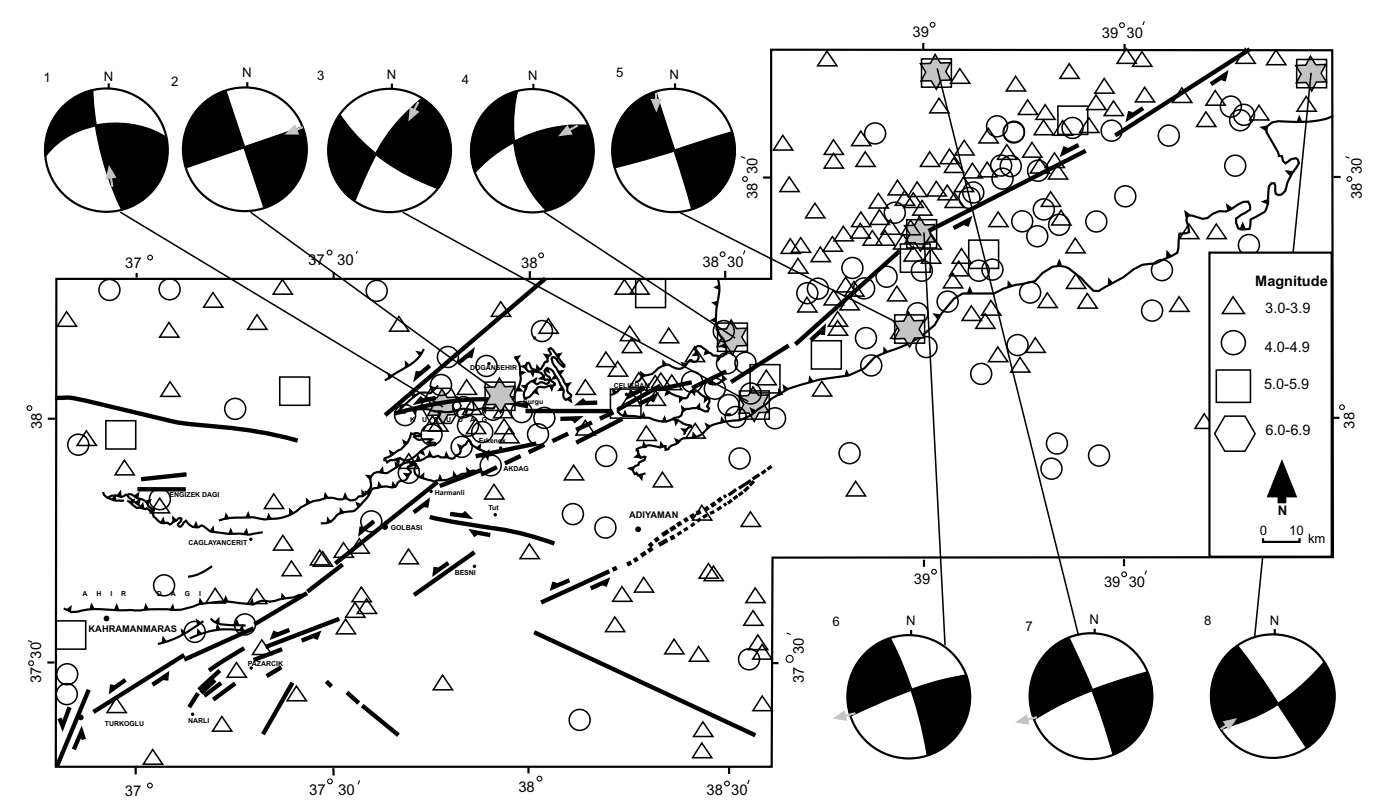

Fig. 5. Seismotectonic map of the study area and vicinity, and focal mechanisms of shallow earthquakes (references are given for each earthquake in Table 3). Plots show nodal planes and slip-vector arrows on the preferred seismic fault planes (arrows point in the direction of the horizontal azimuth of the slip vector); the preferred seismic planes were selected on according to the method of Carey-Gailhardis and Mercier (1987). Numbers outside the beach balls refer to the focal-mechanism labels given in Table 3.

(Nalbant et al., 2002). Despite its high historical seismicity, the current low seismic activity (during the instrumental period) and several geomorphological and structural features (e.g., offset streams, young fault scarps, linear fault lines, triangular facets, and displaced alluvial deposits) indicate active strike-slip faulting along the EAFZ (Saroglu et al., 1992; Cetin et al., 2003). In fact, based on the Coulomb stress-modelling technique, Nalbant et al. (2002) indicated a potential hazard along the segment that was ruptured by the November 29, $1114(M>7.8)$ and March 28, $1513(M>7.4)$ earthquakes between Kahramanmaras and Malatya (Fig. 5). According to authors, the possible future event could be at a magnitude $(M w)$ of 7.3 or larger.

\section{Fault-Kinematics Analysis}

We used the inversion method for fault-kinematics data, as proposed by (Carey, 1979), to compute the directions of compression $\left(\sigma_{1}\right)$ and extension $\left(\sigma_{3}\right)$. For this, we used major and minor fault planes along which significant movement (easily visible at the map or outcrop scale) has occurred. The methodology of fault-kinematics analysis to determine paleostress fields which were active during Late Cenozoic stress states has been applied in a number of tectonically active regions (e.g., Angelier et al., 1981; Sebrier et al., 1988; Mercier et al., 1989, 1991; Bellier and Zoback, 1995; Bellier et al., 1997; Ozden et al., 2002; Over et al., 1997; Over et al., 2002, 2004a, b). Being aware of the limitations of such a method with respect to non-coaxial strains, we implicitly linked the calculated stress direction with the principal strain axes-more properly, the horizontal compressional and extensional directions. On the other hand, the method used in this study allows elucidation of the tectonic regime, with the deviatoric stress ratio " $R$ " defined by the formula $\left[R=\left(\sigma_{2}-\sigma_{1}\right) /\left(\sigma_{3}-\sigma_{1}\right)\right]$, which describes the relative stress magnitudes of the calculated mean devia- toric stress tensor. The $R$ ratio is a linear quantity, and $\sigma_{1}$, $\sigma_{2}$, and $\sigma_{3}$ are, respectively, the compressional, intermediate and extensional deviatoric stress axes. The validity of the stress ratio is confirmed through histograms of the differences between a predicted slip vector (maximum shear, $\tau$ ) and the measured striation $(s)$ (e.g., Carey, 1979; Angelier, 1984). This inversion method has been based on computing a mean best-fitting deviatoric stress tensor from a set of striated faults by minimizing the angular deviation between a predicted slip vector (maximum shear, $\tau$ ) and the measured striation (s) (e.g., Carey, 1979; Angelier, 1984).

The present-day stress regime was determined from the population of focal mechanisms of earthquakes that have occurred in the whole area. We used the inversion statistical method proposed by Carey-Gailhardis and Mercier (1987), which allows calculation of the best-fitting mean stress state from a population of focal mechanisms by selecting one of two nodal planes as the seismic fault plane; this is one of several existing algorithms (Vasseur et al., 1983; Gephart and Forsyth, 1984; Angelier, 2002). The selection can be made by using computer analysis, from co-seismic rupture, or from the spatial epicenter distribution of the aftershock sequence. Indeed, one of the focal-mechanism solutions (i.e., nodal planes) is the seismic fault-slip vector, which is in agreement with the principal stress axes. It is possible to compute the seismic fault slip following the model proposed by Bott (1959). This method requires knowledge of the seismic slip vectors and, consequently, the selection of the preferred seismic fault plane from each pair of nodal planes. This selection is possible by computation: one of the two slip vectors of a focal-mechanism solution is the seismic slip vector in agreement with the principal stress axes. For this slip vector, a stress ratio is computed $(R)$, such that $0<R<1$. If one of the two nodal planes satisfies these conditions, the other does not satisfy it, unless 
Table 1. Locations of fault-striae measurement sites.

\begin{tabular}{|c|c|c|c|c|c|c|c|c|c|}
\hline Site & Latitude $(\mathrm{N})$ & Longitude (E) & Age & Lithology & Site & Latitude $(\mathrm{N})$ & Longitude (E) & Age & Lithology \\
\hline 1 & $37^{\circ} 31^{\prime} 076^{\prime \prime}$ & $37\left(15^{\prime} 981^{\prime \prime}\right.$ & Miocene & clastic & 13 & $37\left(35^{\prime} 194^{\prime \prime}\right.$ & $37^{\circ} 29^{\prime} 010^{\prime \prime}$ & Plio-Pleisto. & marl \\
\hline 2 & $37^{\circ} 31^{\prime} 468^{\prime \prime}$ & $37^{\circ} 17^{\prime} 032^{\prime \prime}$ & Miocene & marl & 14 & $37^{\circ} 40^{\prime} 574^{\prime \prime}$ & $37^{\circ} 29^{\prime} 339^{\prime \prime}$ & Plio-Pleisto. & conglomerate \\
\hline 3 & $37^{\circ} 34^{\prime} 636^{\prime \prime}$ & $37^{\circ} 06^{\prime} 925^{\prime \prime}$ & Miocene & limestone & 15 & $37^{\circ} 44^{\prime} 832^{\prime \prime}$ & $37^{\circ} 34^{\prime} 885^{\prime \prime}$ & Miocene & marl \\
\hline 4 & $37^{\circ} 34^{\prime} 783^{\prime \prime}$ & $37^{\circ} 07^{\prime} 644^{\prime \prime}$ & Mio-Plio. & marl & 16 & $37^{\circ} 48^{\prime} 569^{\prime \prime}$ & $37^{\circ} 41^{\prime} 050^{\prime \prime}$ & Eocene & limestone \\
\hline 5 & $37^{\circ} 35^{\prime} 026^{\prime \prime}$ & $37^{\circ} 12^{\prime} 166^{\prime \prime}$ & Late Cret. & volc. clastic & 17 & $37^{\circ} 50^{\prime} 350^{\prime \prime}$ & $37^{\circ} 44^{\prime} 694^{\prime \prime}$ & Plio-Pleisto. & breccia \\
\hline 6 & $37^{\prime} 36^{\prime \prime} 147^{\prime \prime}$ & $37^{\circ} 15^{\prime \prime} 047^{\prime \prime}$ & Miocene & clastic & 18 & $37^{\circ} 52^{\prime} 000^{\prime \prime}$ & $37^{\circ} 49^{\prime} 775^{\prime \prime}$ & Late Cret. & serpentinite \\
\hline 7 & $37^{\prime} 32^{\prime \prime} 948^{\prime \prime}$ & $37^{\prime} 22^{\prime \prime} 786^{\prime \prime}$ & Miocene & clastic & 19 & $37^{\circ} 49^{\prime} 282^{\prime \prime}$ & $37^{\circ} 40^{\prime} 728^{\prime \prime}$ & Late Cret. & serpentinite \\
\hline 8 & $37^{\circ} 26^{\prime} 584^{\prime \prime}$ & $37^{\circ} 01^{\prime} 195^{\prime \prime}$ & Late Cret. & serpentinite & 20 & $37^{\circ} 50^{\prime} 387^{\prime \prime}$ & $37^{\circ} 42^{\prime} 062^{\prime \prime}$ & Jura-Cret. & limestone \\
\hline 9 & $37^{\circ} 29^{\prime} 613^{\prime \prime}$ & $37^{\circ} 04^{\prime} 307^{\prime \prime}$ & Late Cret. & serpentinite & 21 & $37^{\circ} 55^{\prime} 369^{\prime \prime}$ & $37^{\circ} 51^{\prime} 047^{\prime \prime}$ & Jura-Cret. & limestone \\
\hline 10 & $37^{\circ} 39^{\prime} 430^{\prime \prime}$ & $37^{\circ} 27^{\prime} 605^{\prime \prime}$ & Pleistocene & conglomerate & 22 & $37^{\prime} 55^{\prime \prime} 387^{\prime \prime}$ & $37^{\circ} 53^{\prime} 500^{\prime \prime}$ & Jura-Cret. & limestone \\
\hline 11 & $37^{\circ} 31^{\prime} 367^{\prime \prime}$ & $37^{\circ} 26^{\prime} 332^{\prime \prime}$ & Eocene & limestone & 23 & $37^{\circ} 41^{\prime} 288^{\prime \prime}$ & $37^{\circ} 29^{\prime} 750^{\prime \prime}$ & Miocene & limestone \\
\hline 12 & $37^{\circ} 31^{\prime} 367^{\prime \prime}$ & $37^{\circ} 26^{\prime} 332^{\prime \prime}$ & Eocene & limestone & 24 & $37^{\circ} 59^{\prime} 510^{\prime \prime}$ & $38^{\circ} 11^{\prime} 406^{\prime \prime}$ & Pleistocene & talus \\
\hline
\end{tabular}

the two nodal planes intersect each other along a principal stress axis (Carey, 1979).

The results of the stress inversion are generally considered to be reliable if $80 \%$ of the deviation angles (angle between the calculated slip vector " $\tau$ " and the striation "s") are less than $20^{\circ}$. Note that the state of stress obtained from a set of earthquake focal mechanisms leads to wellconstrained evaluation of the regional stress state, which is in agreement with the state of stress deduced from inversion of the striation measurements on fault planes (Mercier et al., 1991; Bellier et al., 1997; Ozden et al., 2002; Over et al., 2004a).

\section{Results of Fault-Kinematics Analysis \\ 4.1 Late Cenozoic stress regime}

We have performed fault-kinematics analysis at selected sites along the East Anatolian Fault Zone between Turkoglu and Celikhan. Fault-slip measurements from the studied sites are given in Fig. 1, and the location (latitude and longitude) of each site and the ages of the faulted formation from which striae were measured are given in Table 1 . The results based on the inversion of slip vectors, measured on fault planes of various scales which affect Neocene and Quaternary deposits as well as Mesozoic bedrocks, yield a strikeslip stress regime characterized by NNW-SSE $\left(\sigma_{1}\right)$ and ENE-WSW $\left(\sigma_{3}\right)$ stress axes. The inversion results demonstrate strike-slip faulting for all kinematic sites shown in Fig. 6. This regime has produced the left-lateral motion of the major East Anatolian fault. The results of the inversion of all the fault-slip vector datasets belonging to the leftlateral deformation stage correspond to the $\sigma_{1}$ and $\sigma_{3}$ directions shown on the simplified tectonic map of the study area (Fig. 7). The calculated mean deviator of the Fisher statistics yields a regionally significant stress state characterized by a $\sigma_{1}$ axis trending $156 \pm 11^{\circ}$ and a $\sigma_{3}$ axis of $67 \pm 9^{\circ}$, and having plunges of $4^{\circ}$ and $1^{\circ}$, respectively (Table 2; Fig. 6 ; note that the quoted azimuthal errors of $11^{\circ}$ and $9^{\circ}$ correspond to the radius of the $95 \%$ cone of confidence of Fisher statistics).

The stress ratio defines the shape of the stress ellipsoid. To compare R-values of distinct stress deviators in terms of stress-magnitude variation, it is necessary for the compared stress deviators to be coaxial (i.e., they must have the same principal axis directions) in order to be represented on a Mohr's circle. A discussion of the stress-ratio significance in interpreting inversion results was presented by Bellier and Zoback (1995). As defined above, the $R$-value varies between two end-member uniaxial stress states; that is $R=0$ when $\sigma_{2}=\sigma_{1}$, and $R=1$ when $\sigma_{2}=\sigma_{3}$. In a strike-slip-faulting stress regime (where vertical stress $\sigma_{v}=\sigma_{2}$, maximum horizontal stress $\sigma_{H \max }=\sigma_{1}$, and minimum horizontal stress $\sigma_{H \text { min }}=\sigma_{3}$ ), the $R=0$ end member corresponds to a stress state transitional to normal faulting (extensional regime), in which $\sigma_{H \max }=\sigma_{v}$, whereas the $R=1$ end member represents a stress state transitional to thrust faulting (compressional regime), in which $\sigma_{H \text { min }}=\sigma_{v}$. For $R$-values close to 0 or to 1 (e.g., $0.85<R<1$ and $0<R<0.15)$, the near-transitional stress states require only minor fluctuations in stress magnitude to change from strike-slip to normal faulting or to thrust faulting. Thus, such deformations are characterized by mixed modes of faulting: dip-, oblique- and strike-slip. For triaxial deviators, R-values higher than 0.55 represent transpressional strike-slip regimes in which $\sigma_{2}$ is tensional, whereas R-values lower than 0.45 correspond to transtensional regimes in which $\sigma_{2}$ is compressional (Figs. 6, 7; Table 2).

In this study, the calculated $\mathrm{R}$ values are higher than 0.55 for sites $1-2,4,5-6,8,9,10-12,17-18$, and 20 , corresponding to transpressional strike-slip regimes in which (2 is tensional; they are less than 0.45 for sites $3,7,13,14$, $15,16,19,21-22$, and 23-24, corresponding to transtensional strike-slip regimes in which $\sigma_{2}$ is compressional (see Methodology section). Unfortunately, we observed no structural evidence that would allow the two different stages to be distinguished within the strike-slip regime. However, based on slip-vector inversion and relative chronologies among striations, Over et al. (2002, 2004a, b) observed and distinguished old transpressional and young transtensional stress regimes along the southern part of East Anatolian Fault between Turkoglu and Antakya.

\subsection{Present-day stress regime}

Available focal mechanisms for earthquakes of magnitudes greater than $M=5.0$ for the period between 1964 and 2004 are shown in Fig. 5. We have used eight mechanisms, corresponding to the events located within the study area and vicinity (provided by Buyukasikoglu, 1980, Taymaz et al., 1991, and the Harvard CMT catalogue 

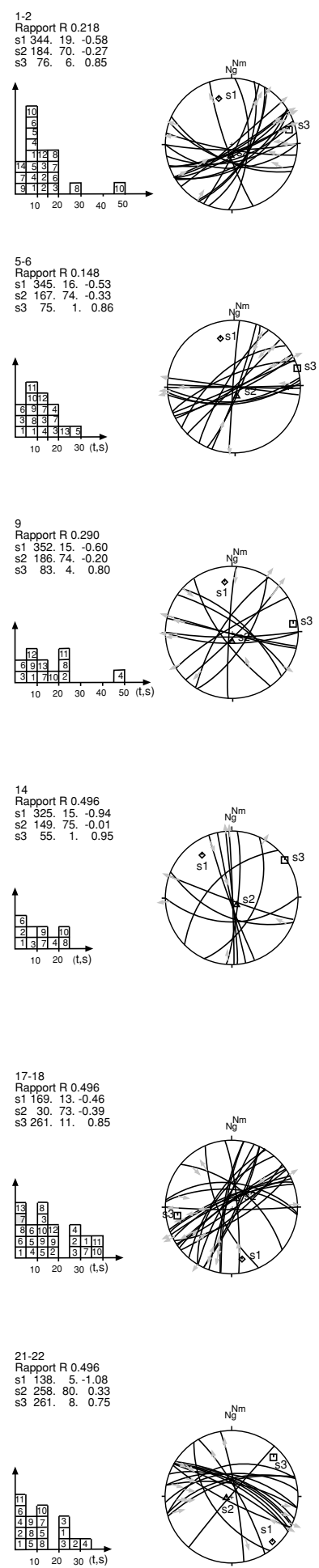
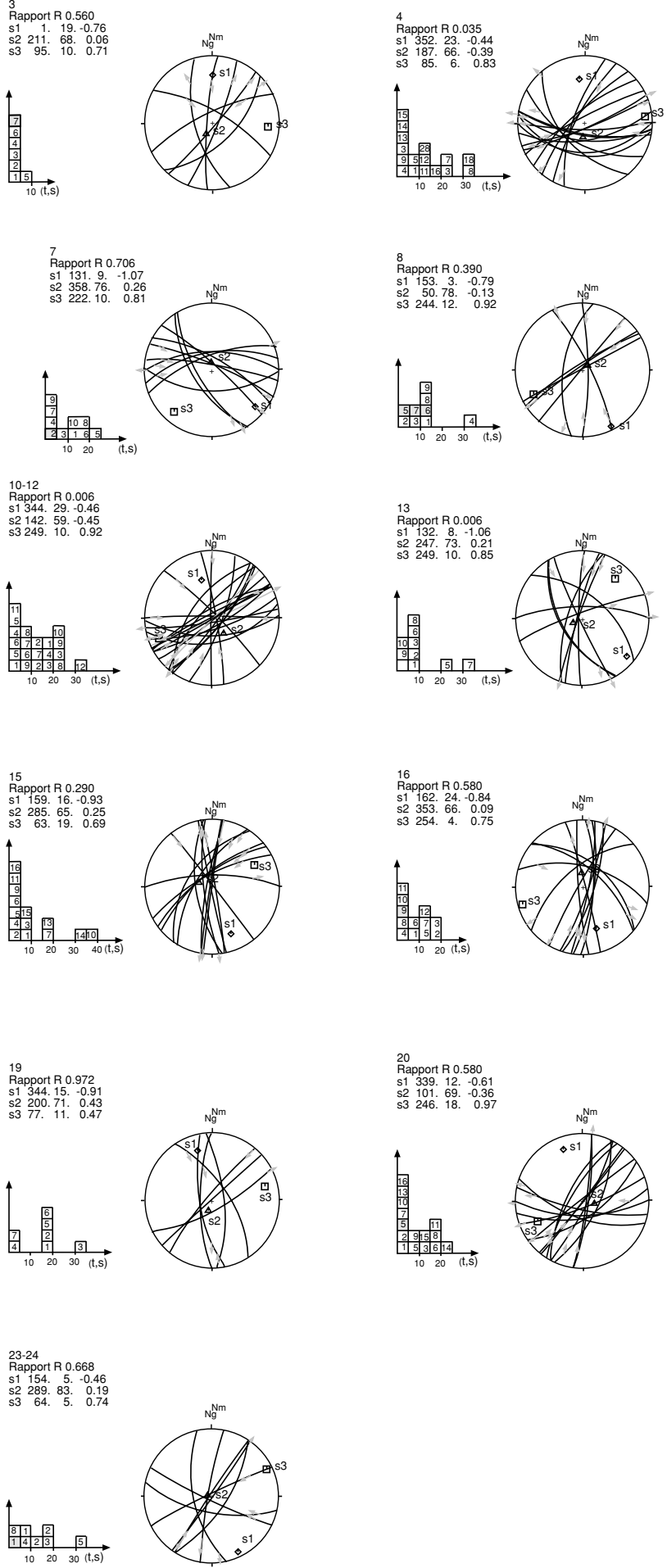

Fig. 6. Lower-hemisphere stereoplots show strike-slip fault data measured in the study area and the results obtained using Carey's (1979) inversion method, as given in Table 2. Labels to the left of the stereonets refer to sites shown in Fig. 1 and listed in Table 1. The results include deviatoric stress parameters shown by diamonds $\left(\sigma_{1}\right)$, triangles $\left(\sigma_{2}\right)$ and squares $\left(\sigma_{3}\right)$. Histogram shows distribution of deviation angles (angle between the observed slip, s, and the predicted slip, $\tau$ ).

(www.seismology.harvard.edu/CMTsearch)) (Table 3). The inversions of focal mechanisms yield a strike-slip stress deviator characterized by an approximately N-S (N1(W)trending $\sigma_{1}$ and an approximately E-W (N89(E)-trending $\sigma_{3}$ axis for the area between Turkoglu and Celikhan (Fig. 8). The computed stress ratio ( $R$-value) is 0.715 , indicating that this stress regime is transpressional; i.e., the inter- mediate stress axis $\left(\sigma_{2}\right)$ is tensional. The compressional structures were observed both in this and previous studies (e.g., Yalcin, 1979; Lyberis et al., 1992; Chorowicz et al., 1994). Nevertheless, Over et al. (2004a, b) suggested that the present-day stress regime is transtensional in the southern part of the EAFZ between Turkoglu and Antakya. Indeed, both the inversions of the fault slip-vectors recorded 
Table 2. Results of stress-tensor inversions from fault-slip data sets.

\begin{tabular}{|c|c|c|c|c|c|c|c|}
\hline Sites $^{\mathrm{a}}$ & $N^{\mathrm{b}}$ & $\sigma_{1} \mathrm{Az} /$ plunge $^{\mathrm{c}}$ & $\sigma_{2} \mathrm{Az} /$ plunge $^{\mathrm{c}}$ & $\sigma_{3} \mathrm{Az} /$ plunge $^{\mathrm{c}}$ & $R$ & M.D. ${ }^{d}$ & S.D. ${ }^{e}$ \\
\hline $1-2$ & 21 & $344 / 19$ & $184 / 70$ & $76 / 6$ & 0.22 & 12.0 & 15.7 \\
\hline 3 & 7 & $1 / 19$ & $211 / 68$ & $95 / 10$ & 0.56 & 3.0 & 3.5 \\
\hline 4 & 16 & $352 / 23$ & $187 / 66$ & $85 / 6$ & 0.04 & 12.0 & 15.8 \\
\hline $5-6$ & 17 & $345 / 16$ & $167 / 74$ & $75 / 1$ & 0.15 & 11.1 & 13.2 \\
\hline 7 & 10 & $131 / 9$ & $358 / 76$ & $222 / 10$ & 0.71 & 9.4 & 11.8 \\
\hline 8 & 9 & $153 / 3$ & $50 / 78$ & $244 / 12$ & 0.39 & 10.8 & 13.5 \\
\hline 9 & 12 & $352 / 15$ & $186 / 74$ & $83 / 4$ & 0.29 & 14.7 & 18.7 \\
\hline $10-12$ & 21 & $344 / 29$ & $142 / 59$ & $249 / 10$ & 0.01 & 12.0 & 14.8 \\
\hline 13 & 10 & $132 / 8$ & $247 / 73$ & $40 / 16$ & 0.67 & 8.8 & 12.2 \\
\hline 14 & 10 & $325 / 15$ & $149 / 75$ & $55 / 1$ & 0.50 & 10.3 & 12.5 \\
\hline 15 & 14 & $159 / 16$ & $285 / 65$ & $63 / 19$ & 0.73 & 9.5 & 14.5 \\
\hline 16 & 12 & $162 / 24$ & $353 / 66$ & $254 / 4$ & 0.58 & 7.9 & 9.9 \\
\hline $17-18$ & 23 & $169 / 13$ & $30 / 73$ & $261 / 11$ & 0.06 & 15.6 & 19.5 \\
\hline 19 & 7 & $344 / 15$ & $200 / 71$ & $77 / 11$ & 0.97 & 14.8 & 17.7 \\
\hline 20 & 15 & $339 / 12$ & $101 / 69$ & $246 / 18$ & 0.16 & 8.6 & 11.0 \\
\hline $21-22$ & 17 & $138 / 5$ & $258 / 80$ & $47 / 8$ & 0.77 & 12.8 & 15.4 \\
\hline $23-24$ & 8 & $154 / 5$ & $289 / 83$ & $64 / 5$ & 0.67 & 11.9 & 14.9 \\
\hline SS. $1^{\text {f }}$ & & \multicolumn{4}{|c|}{$\sigma_{1}=156 / 11^{\circ}$ and $\sigma_{3}=67 / 9^{\circ} R m=0.44^{\mathrm{g}}$} & 10.9 & 13.8 \\
\hline
\end{tabular}

a“"-" indicates an inversion solution computed from two data sets from different sites. For example, 10-12 corresponds to an inversion computed from the data sets of sites 10,11 and 12 .

${ }^{\mathrm{b}} N=$ number of striated fault planes used to compute the solutions.

${ }^{\mathrm{c}}$ Deviatoric principal stress axes, $\sigma_{1}, \sigma_{2}$ and $\sigma_{3}$ are the compressional, intermediate and extensional deviatoric axes, respectively.

${ }^{\mathrm{d}}$ The mean deviation of the deviation angle is "M.D." $=\left[\sum(\tau, s)^{2}\right] / N$, where $(\tau, s)$ is the angle between the predicted slip vector $(\tau)$ and observed slip vector $(s)$.

"The standard deviation of the deviation angle is "S.D." $=\left\{\left[\sum(\tau, s)^{2}\right] / N\right\}^{1 / 2}$.

${ }^{\mathrm{f}} \mathrm{SS} .1$ is an average stress state obtained from computing mean stress axes using Fisher statistics on individual horizontal $\sigma_{1}$ and $\sigma_{3}$ axes.

${ }^{\mathrm{g}} \mathrm{Rm}$ value is an arithmetic mean of all sites.

Table 3. Parameters of focal mechanisms of shallow earthquakes from the study area and vicinity.

\begin{tabular}{|c|c|c|c|c|c|c|c|c|}
\hline No & Date & $\begin{array}{l}\text { Lat N } \\
\text { (deg) }\end{array}$ & $\begin{array}{l}\text { Long E } \\
\text { (deg) }\end{array}$ & $\begin{array}{c}\text { Planes } 1 \\
\text { strike }^{\circ} / \text { dip }^{\circ} / \text { Rake }^{\circ}\end{array}$ & $\begin{array}{c}\text { Plane } 2 \\
\text { strike }^{\circ} / \text { dip }^{\circ} / \text { Rake }^{\circ}\end{array}$ & $\begin{array}{c}\mathrm{M} \\
(M w)\end{array}$ & $\begin{array}{c}\mathrm{h} \\
(\mathrm{km})\end{array}$ & $\operatorname{Ref}^{\circ}$ \\
\hline 1 & 05.05 .1986 & 37.72 & 37.70 & $260 / 54 / 9$ & $164 / 82 / 144$ & 6.0 & 15 & 3 \\
\hline 2 & 06.06 .1986 & 37.36 & 37.99 & $160 / 90 / 0$ & $250 / 90 / 180$ & 5.8 & 15 & 3 \\
\hline 3 & 14.06 .1964 & 38.10 & 38.50 & $28 / 77 / 6$ & $122 / 75 / 168$ & $5.9(\mathrm{Ms})$ & 8 & 1 \\
\hline 4 & 30.10 .1968 & 37.87 & 38.57 & $65 / 69 / 166$ & $164 / 67 / 16$ & $5.0(\mathrm{Ms})$ & 3 & 2 \\
\hline 5 & 13.07.2003 & 38.16 & 38.90 & $72 / 89 / 1$ & $342 / 89 / 179$ & 5.5 & 15 & 3 \\
\hline 6 & 09.05.1998 & 38.19 & 39.00 & $251 / 83 /-7$ & $341 / 83 /-173$ & 5.1 & 15 & 3 \\
\hline 7 & 11.08 .2004 & 38.50 & 39.09 & $335 / 86 /-173$ & $245 / 83 /-4$ & 5.6 & 14.3 & 3 \\
\hline 8 & 25.03 .1977 & 38.58 & 39.82 & $55 / 77 / 1$ & $324 / 89 / 167$ & 5.3 & 21 & 3 \\
\hline
\end{tabular}

${ }^{a}$ References: 1, Jackson and McKenzie (1984); 2, Buyukasikoglu (1980); 3, Harvard CMT Catalogues.

by brittle deformation and the seismic fault slip deduced from the earthquake focal mechanisms lead us to conclude that the regionally significant recent-to-present-day stress regime is one of strike-slip faulting. This stress regime is consistent with the N-to NW-trending $\sigma_{1}$ and the E- to NEtrending $\sigma_{3}$ axes that produce left-lateral motion along the EAFZ (Figs. 5, 8; Table 3).

The N- to NNE- $\sigma_{1}$ axis direction related to transpression (i.e., strike-slip to oblique-reverse) was probably responsi- ble for the compressional structures observed both in this and previous studies (e.g., Lyberis et al., 1992; Chrorowicz et al., 1994; Yalcin, 1979), as indicated by earthquake focal mechanisms. Thus, six of the eight mechanisms have strikeslip motion with reverse components (events no.: 1, 2, 3, 4, 5 and 7; see Figs. 5, 8; Table 3), while only two events have strike-slip motion with normal components (events no.: 6 and 8; see Figs. 5, 8; Table 3). 


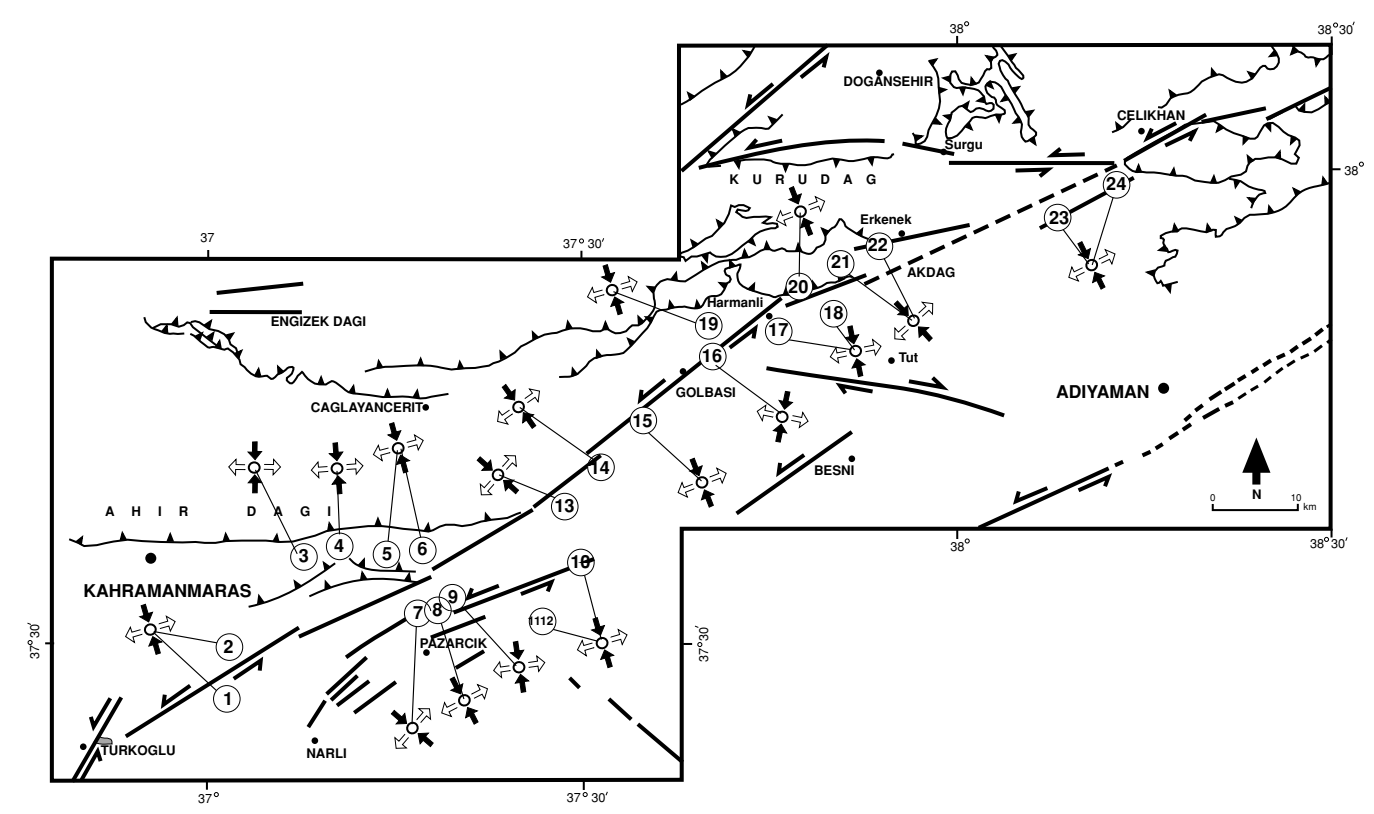

Fig. 7. Simplified tectonic map of the study area. Black arrows indicate the $\sigma_{1}$ azimuth, while white arrows indicate the $\sigma_{3}$ azimuth. Numbers mark the locations of fault-slip measurement sites listed in the Table 1, and results of the stress axes given in Table 2.

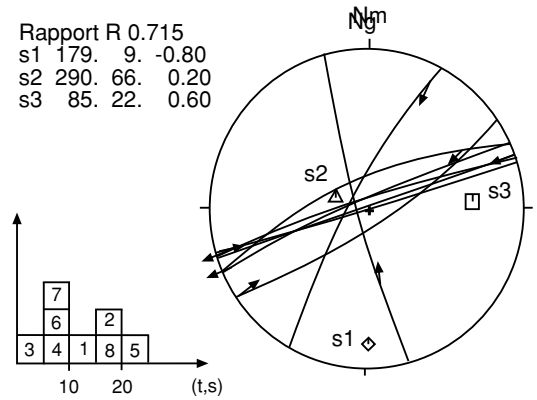

Fig. 8. Lower-hemisphere stereoplots of earthquake slip data with present-day principal stress directions computed from the focal mechanisms of earthquakes shown in Table 3. See caption for Fig. 6.

\section{Discussion and Conclusions}

The Neocene stress regime operating in the study area has a strike-slip character with a reverse component (i.e., transpression). This regime seems to be continuing, as indicated by inversions of focal mechanisms of earthquakes greater than 5.0 in magnitude (Fig. 8). This regime, consistent with NNW-trending $\sigma_{1}$ and ENE-trending $\sigma_{3}$ axes, produces left-lateral motion along the EAFZ and was probably responsible for the Mio-Pliocene compressional structures observed in the study area. The $R$-values obtained from inversion show that some results (sites 1-2, 4, 5-6, 8, 9, 10-12, 17-18 and 20; see Table 2; Fig. 7) are higher than 0.55 , indicating a transpressional regime (strike slip with a reverse component), whereas some are less than 0.45 (sites 3, 7, 13, 15, 16, 19, 21-22 and 23-24; see Table 2; Fig. 7), indicating a transtensional strike-slip regime (strike slip with a normal component) (see Methodology section). Note that our observations show that compressive features are more remarkable than extensional ones throughout the study area and that the left-lateral EAFZ developed during and/or after a folding-thrusting deformation stage since (at least) the Pliocene. However, we have gathered no structural evidence in the field that would indicate a change in these distinct strike-slip regimes. Significantly, Over et al. (2002, 2004a, b), based on slip-vector inversion and relative chronologies among striations, observed and distinguished old transpressional and young transtensional stress regimes along the southern part of the East Anatolian Fault between Turkoglu and Antakya. They also determined that the transtensional stress regime, which is regionally significant, is continuing. The transtensional tectonic stress regime seems to affect a large area (Robertson et al., 1991; Kempler and Garfunkel, 1994; Bellier et al., 1997; Over et al., 2002, 2004a, b), implying that the lithosphere of the Anatolian block is subjected to extension (Chorowicz et al., 1999). These compressive structures (i.e., thrust faulting, folds etc.) obviously belong to primary stage of the continental collision but are still active with lesser importance in the Eastern Anatolian plateau (Orgulu et al., 2003).

The stress regime determined here probably resulted from several coeval influences on the geodynamic context of the region: Arabian/Anatolian continental collision in the east, African/Anatolian subduction in the south-southwest (i.e., along the Cyprus Arc), and westward extrusion of the Anatolian block.

Acknowledgments. This study was financially supported through Project No. M-233, Cumhuriyet University Research Foundation (CUBAP; Sivas, Turkey). We also thank CUBAP for its logistical support and Dr. Steve Mitwede for English grammatical revision of the paper. The authors wish to thank Dr. Ali Pınar and Dr. Suleyman Nalbant for their constructive and critical review of this manuscript and many helpful comments suggested.

\section{References}

Allen, C. R., Active faulting in northern Turkey, Division of Geological Science, Calif. Inst. Technol. Contrib., 1577, 32, 1969.

Ambraseys, N. N., Some characteristic features of the Anatolian fault zone, Tectonophysics, 9, 143-165, 1970. 
Ambraseys, N. N., Temporary seismic quiescence: SE Turkey, Geophys. J., 96, 311-331, 1989.

Ambraseys, N. N. and C. P. Melville, Historical evidence of faulting in eastern Anatolia and northern Syria, Ann. Geophys., 38, 337-344, 1995.

Ambraseys, N. N. and J. A. Jackson, Faulting associated with historical and recent earthquakes in the eastern Mediterranean region, Geophys. $J$. Int., 133, 390-406, 1998 .

Ambraseys, N. N. and M. Barazangi, The 1759 earthquake in the Bekaa Valley: implications for earthquake hazard assessment in the eastern Mediterranean region, J. Geophys. Res., 94, 4007-4013, 1989

Angelier, J., Tectonic analysis of fault slip data sets, J. Geophys. Res., 89, 5835-5848, 1984

Angelier, J., Inversion of earthquake focal mechanisms to obtain the seismotectonic stress IV - a new method free of choice among nodal planes, Geophy. J. Int., 150(3), 588-609, 2002.

Angelier, J., J. F. Dumont, H. Karamanderesi, A. Poisson, S. Simsek, and S. Uysal, Analysis of mechanisms and expansion of south-western Anatolia since the Late Miocene, Tectonophysics, 75, T1-T9, 1981.

Arpat, E. and F. Saroglu, The East Anatolian fault system: thoughts on its development, M.T.A. Bull., 78, 33-39, 1972.

Arpat, E. and F. Saroglu, Turkiye'deki bazi onemli genc tektonik olaylar, Bull. Geol. Soc. Turkey, 18/1, 91-101, 1975.

Barka, A. A. and K. Kadinsky-Cade, Strike-slip fault geometry in Turkey and its fluence on earthquake activity, Tectonics, 7/3, 663-684, 1988.

Bellier, O. and M. Zoback, Recent state of stress change in the Walker Lane zone western basin and Range Province-USA, Tectonics, 14, 564-593, 1995.

Bellier, O., S. Over, A. Poisson, and J. Andrieux, Recent temporal change in the stress state and modern stress field along North Anatolian Fault Zone (Turkey), Geophys. J. Int., 131, 61-86, 1997.

Bilgic, T., 1/ 500000 Scale geological map of Turkey, Sivas sheet, MTA, Ankara, 2002

Bott, M. H. P., The mechanism of oblique slip faulting, Geol. Mag., 96, 109-117, 1959.

Buyukasikoglu, S., Sismolojik verilere gore dogu akdenizin kuzeyinde ve guneydogu Anadolu'da Avrasya-Afrika levha sinirlarinin ozellikleri, Bull. Earthquake Res. Inst. (Ministry of Reconstruction and Resettlement), 29, 58-74, 1980 (in Turkish).

Carey, E., Recherche des directions principales de contraintes associées au jeu d'une population de failles, Rev. Geol. Dynam. Geog. Phys., 21, 57-66, 1979.

Carey-Gailhardis, E. and J. L. Mercier, A numerical method for determining the state of stress using focal mechanisms of earthquake populations, Earth Planet. Sci. Lett., 82, 165-179, 1987.

Cetin, H., H. Guneyli, and L. Mayer, Paleoseismology of the Palu-Lake Hazar segment of the East Anatolian Fault Zone, Turkey, Tectonophysics, 374, 163-197, 2003.

Chorowicz, J., P. Luxey, N. Lybéris, J. Carvalho, J. F. Parrot, T. Yurur, and N. Gundogdu, The Maras Triple Junction (southern Turkey) based on digital elevation model and satellite imagery interpretation, J. Geophys. Res., 99, 20225-20242, 1994.

Chorowicz, J., D. Dhont, and N. Gundogdu, Neotectonics in the eastern North Anatolian Fault region (Turkey) advocates crustal extension: mapping from SAR ERS imagery and Digital Elevation Model, J. Struct. Geol., 21, 511-532, 1999.

Dewey, J. F. and A. M. C. Sengor, Aegean and surrounding regions: complex multi-plate and continuum tectonics in a convergent zone, Geol. Soc. Am. Bull., 90, 84-92, 1979.

Dewey, J. F., M. R. Hempton, W. S. F. Kidd, F. Saroglu, and A. M. C. Sengor, Shortening of continental lithosphere: the neotectonics of Eastern Anatolia- a young collision zone, in Collision Tectonics, edited by M. P. Coward and A. C. Ries, Geol. Soc. London Sp. Pub., 19, 3-36, 1986.

Ergin, K., U. Guclu, and Z. Uz, A catalogue of earthquakes for Turkey and surrounding area (11AD to 1964AD), Tech. Univ. Mining Eng. Fac. Publ., 24, 189, 1967

Gephart, J. W. and D. W. Forsyth, An improved method for determining the regional stress tensor using earthquake focal mechanism data: an application to the San Fernando earthquake sequence, J. Geophys. Res., 89, 9305-9320, 1984.

Hempton, M. R., Constraints on Arabian plate motion and extensional history of the Red Sea, Tectonics, 6, 687-705, 1987.

Hempton, M. R., J. F. Dewey, and F. Saroglu, The East Anatolian transform fault: along strike variations in geometry and behavior, EOS Trans., 62 , 393, 1981 .

Imamoglu, M. S., Golbasi (Adiyaman)-Pazarcik-Narli (K. Maras) arasin- daki sahada Dogu Anadolu Fayi'nin neotektonik incelemesi. Doktora Tezi, A.U. Fen Bilimleri Enstitusu Jeoloji Muh. Anabilim Dali, Ankara, 137 pp., 1993.

Jackson, J. and D. P. McKenzie, Active tectonics of the Alpine-Himalayan belt between western Turkey and Pakistan, Geophys. J. R. Astron. Soc., 77, 185-264, 1984.

Jackson, J. and D. P. McKenzie, The relationship between plate motion and seismic moment tensors, and the rates of active deformation in the Mediterranean and Middle-East, Geophys. J. R. Astron. Soc., 93, 45-73, 1988.

Karig, D. E. and H. Kozlu, Late Paleogene-Neogene evolution of the triple junction region near Maras, south-central Turkey, J. Geol. Soc. London, 147, 1023-1034, 1990.

Kempler, D. and Z. Garfunkel, Structures and kinematics in the northeastern Mediterranean: a study of an irregular plate boundary, Tectonophysics, 234, 19-32, 1994

Keskin, M., Magma generation by slab steepening and breakoff beneath a subduction-accretion complex: an alternative model for collision-related volcanism in Eastern Anatolia, Turkey, Geophys. Res. Lett., 30/24 8046, 2003

Lyberis, N., T. Yurur, J. Chorowicz, E. Kasapoglu, and N. Gundogdu, The East Anatolian Fault: an oblique collisional belt, Tectonophysics, 204, $1-15,1992$.

McClusky, S., S. Balassanian, A. Barka, C. Demir, S. Ergintav, İ. Georgiev, O. Gurkan, M. Hamburger, K. Hurst, H. Kahle, K. Kastens, G Kekelidze, R. King, V. Kotzev, O. Lenk, S. Mahmoud, A. Mishin M. Nadariya, A. Ouzounis, D. Paradissis, Y. Peter, M. Prilepin, R. Reilinger, I. Sanli, H. Seeger, A. Tealeb, M. N. Toksoz, and G. Veis, Global Positioning System constraints on plate kinematics and dynamics in the eastern Mediterranean and Caucasus, J. Geophys. Res. 105(B3), 5695-5719, 2000 .

McKenzie, D. P., Active tectonics of the Mediterranean Region, Geophys J. R. Astron. Soc., 30, 109-185, 1972.

Mercier, J. L., D. Sorel, and P. Vergely, Extensional tectonic regimes in the Aegean basins during the Cenozoic, Basin Res., 2, 49-71, 1989.

Mercier, J. L., E. Carey-Gailhardis, and M. Sébrier, Paleostress determinations from fault kinematics: application to the neotectonics of the Himalayas-Tibet and the Central Andes, Phil. Trans. R. Soc. Lond. A, 337, 41-52, 1991.

Nalbant, S. S., J. McCloskey, S. Steacy, and A. A. Barka, Stress acumulation and increased seismic risk in eastern Turkey, Earth Planet. Sci. Lett., 195, 291-298, 2002.

Orgulu, G., M. Aktar, N. Turkelli, E. Sandvol, and M. Barazangi, Contribution to the seismotectonics of the Eastern Anatolian Plateau from moderate and small size events, Geophys. Res. Lett., 30/24, 8040, 2003.

Over, S., O. Bellier, A. Poisson, and J. Andrieux, Late Cenozoic stress state changes along the central North Anatolian Fault zone (Turkey), Ann. Tectonicae, XI, 1-2, 75-101, 1997.

Over, S., U. C. Unlugenc, and O. Bellier, Quaternary stress regime change in the Hatay region (SE Turkey), Geophys. J. Int., 148, 1-14, 2002.

Over, S., S. Ozden, and H. Yilmaz, Late Cenozoic stress evolution along the Karasu Valley, SE Turkey, Tectonophysics, 380, 43-68, 2004a.

Over, S., S. Ozden, U. C. Unlugenc, and H. Yilmaz, A synthesis Late Cenozoic stress field distribution at northeastern corner of the eastern Mediterranean, SE Turkey, C.R. Geoscience, 336, 93-103, 2004b.

Over, S., K. S. Kavak, O. Bellier, and S. Ozden, Is the Amik Basin (SETurkey) a Triple Junction Area? Analyses of SPOT XS Imagery and Seismicity, Int. J. Remote Sensing, 25/19, 3857-3872, 2004c.

Ozden, S., S. Over, and U. C. Unlugenc, Quaternary stress regime change along the eastern North Anatolian Fault Zone, Turkey, Int. Geol. Review, 44/11, 1037-1052, 2002.

Perincek, D. and I. Cemen, The structural relationship between the East Anatolian Fault and Dead Sea Fault zones in southern Turkey, Tectonophysics, 172, 331-340, 1990.

Poirier, J. P. and M. A. Taher, Historical seismicity in the Near and Middle East, North Africa and Spain from Arabic documents, Bull. Seism. Soc. Am., 70, 2185-2201, 1980.

Reilinger, R. E., S. C. McClusky, M. B. Oral, R. W. King, M. N. Toksoz, A. A. Barka, I. Kinik, O. Lenk, and I. Sanli, Global Positioning System measurements of present-day crustal movements in the Arabia-AfricaEurasia plate collision zone, J. Geophys. Res.-Solid Earth, 102(B5), 9983-9999, 1997.

Robertson, A. H. F., S. Eaton, E. J. Follows, and J. E. McCullum, The role of local tectonics versus global sea-level change in the Neogene evolution of the Cyprus active margin, Spec. Publ. Int. Ass. Sediment, 12, 331-369, 1991. 
Sandvol, E., N. Turkelli, and M. Barazangi, The Eastern Turkey Seismic Experiment: The study of a young continent-continent collision, Geophys. Res. Lett., 30/24, 8038, 2003.

Saroglu, F., O. Emre, and A. Boray, Turkiye'nin diri faylari ve depremsellikleri, Min. Res. Expl. Inst. Turkey Rept. No. 8174, 1987.

Saroglu, F., O. Emre, and I. Kuscu, The East Anatolian fault zone of Turkey, Ann. Tectonicae, VI, 99-125, 1992.

Sebrier, M., J. L. Mercier, J. Macharé, D. Bonnot, J. Cabrera, and J. L. Blanc, The state of stress in an overridding plate situated above a flat slab: the Andes of central Peru, Tectonics, 7, 895-928, 1988.

Sengor, A. M. C., Northern Anatolian fault: Its age offset and tectonic significance, J. Geol. Soc. London, 136, 269-282, 1979.

Sengor, A. M. C. and Y. Yilmaz, Tethyan evolution of Turkey. A plate tectonic approach, Tectonophysics, 75, 181-241, 1981.

Sengor, A. M. C., N. Gorur, and F. Saroglu, Strike-slip faulting and related basin formation in zones of tectonic escape: Turkey as a case study, in Strike-slip Deformation, Basin Formation and Sedimentation, edited by K. T. Biddle and N. Christie-Blick, Soc. Econ. Paleont. Mineral. Tulsa, Sp. Publ. 37, 227-264, 1985.

Seymen, I. and A. Aydin, Bingol deprem fayi ve bunun Kuzey Anadolu Fayi ile iliskisi, M.T.A. Bull., 79, 33-39, 1972.

Sieberg, A., Erdbebengeographic, in Handbuch der Geophysic, edited by B. Gutenberg, Bands IV, Borntrager, Berlin, pp. 527-1005, 1932.

Soysal, H., S. Sipahioglu, D. Kolcak, and Y. Altinok, Turkiye Tarihsel Deprem Katalogu, TUBITAK Proje No. TBAG-341, 1981.

Taymaz, T., H. Eyidogan, and J. Jackson, Source parameters of large earthquakes in the East Anatolian Fault Zone (Turkey), Geophys. J. Int., 106/3, 537-550, 1991.

Turkelli, N., E. Sandvol, E. Zor, R. Gok, T. Bekler, A. Al-Lazki, H. Karabulut, S. Kuleli, T. Eken, C. Gurbuz, S. Bayraktutan, D. Seber, and M. Barazangi, Seismogenic zones in eastern Turkey, Geophys. Res. Lett., 30/24, 8039, 2003.

Ulu, U., 1/500,000 Scale geological map of Turkey, Hatay sheet, MTA, Ankara, 2002.

Vasseur, G., A. Etchecopar, and H. Philip, Stress state inferred from mul- tiple focal mechanisms, Ann. Geophys., 1, 291-298, 1983.

Westaway, R., Kinematics of the Middle East and eastern Mediterranean updated, Turkish J. Earth Sci., 12, 5-46, 2003.

Westaway, R. and J. Arger, Kinematics of the Malatya-Ovacik fault zone. Third International Turkish Geology Symposium, METU-Ankara, Abstracts, 197, 1998.

Willis, B., Earthquakes in the Holy Land, Bull. Seism. Soc. America, 18, 73-103, 1928.

Yalcin, N., Dogu Anadolu Yarilimi'nin Turkoglu Karaagac (K. Maras) arasindaki kesiminin ozellikleri ve bolgedeki yerlesme alanlari, Turk. Jeoloji Kurumu Altinli Sempozyumu, 19-56, 1979.

Yazgan, E. and R. Chessex, Geology and tectonic evolution of the southeastern Taurides in the region of Malatya, TAPG Bull., 3/1, 1-42, 1991.

Yilmaz, Y., Allochthonous terranes in the Tethyan Middle East: Anatolia and the surroundings regions, $R$. Soc. Lond. Philos. Transact, A331, 611-624, 1990.

Yilmaz, Y., New evidence and model on the evolution of the southeast Anatolian orogeny, Geol. Soc. Am. Bull., 105, 251-271, 1993.

Yilmaz, Y., O. Gurpinar, H. Kozlu, M. A. Gul, E. Yigitbas, M. Yildirim, C. Genc, and M. Keskin, Maras kuzeyinin jeolojisi (Andirin-BeritEngizek-Nurhak-Binboga Daglari), Turk, Petrolleri Anonim Ortakligi Rapor No. 2028/2, 218 pp., 1987.

Yurur, T. and J. Chorowicz, Recent volcanism, tectonics and plate kinematics near the junction of African, Arabian and Anatolian plates in the eastern Mediterranean, J. Volcanol. Geothermal Res., 85, 1-15, 1998.

Zanchi, A. and J. Angelier, Seismotectonics of western Anatolia: regional stress orientation from geophysical and geological data, Tectonophysics, 222, 259-274, 1993.

Zor, E., E. Sandvol, C. Gurbuz, N. Turkelli, D. Seber, and M. Barazangi, The crustal structure of the East Anatolian plateau (Turkey) from receiver functions, Geophys. Res. Lett., 30/24, 8044, 7.1-4, 2003.

H. Yilmaz (e-mail: yilmazh@cumhuriyet.edu.tr), S. Over, and S. Ozden 